\title{
DETERMINING THE VALIDITY OF A PATENT ON DEMURRER TO A BILL IN EQUITY.
}

Probably in no branch of Federal Practice have the length and cost of the records become so voluminous as in patent cases. Nowhere else are the rules of evidence so grossly disregarded as in the taking of proofs in this class of cases. The length and irrelevance of cross examination have become a burden to courts and the contesting parties, and in several cases recently this tendency has been severely reprimanded by the courts. $^{1}$ Undoubtedly the circumstances under which the evidence in such causes is taken-before an examiner who has no power to exclude anything-tend to produce such unscientific and exhaustive records as are frequently presented to the court. When we count the fees of counsel and witnesses, the services of the master and stenographer or type writer, the printing, sometimes done twice, and the time and labor expended by the counsel and court in threshing out the wheat from the straw on the final hearing, we can readily imagine the enormous expense of an elaborate patent suit. The result of this tendency is not only in severe reprimands by the courts, but in a growing desire to dispose of the vital question in a patent case before the final hearing. To this desire is undoubtedly due the practice which is the subject of this paper.

This practice is substantially as follows: Where a bill of equity prays for an injunction against the infringement of a patent, the defendant may raise the question of the validity of the patent in suit, not only by answer and proof, but also by demurrer to the bill on the ground that the patent is invalid on its face. Necessarily the practice of demurring to the bill on this ground must be limited in its application, as ordinarily it is impossible for the courts to pass on a complex and intricate patent without the assistance of proofs. On the other hand, where the patent is for a simple device which relates to a familiar subject, and may be easily understood without the aid of expert

${ }^{1}$ Ecaubert v. Appleton, 67 F. R. 924; City of Carlsbad v. Kutnow, 7r F. R. 172. 
testimony or extrinsic evidence, the courts have generally accepted the doctrine that the validity of the patent may be determined on demurrer to the original bill, and in some circuits a number of cases have been disposed of in this manner.

It is the purpose of this paper to review briefly a number of the leading cases of the different circuit and Supreme Courts in an endeavor to ascertain the various conditions, limitations, and tests applicable in the conduct of cases of this description. The practice appears to be of recent growth, the cases are still few in number, and only during the last year or two has the practice been stamped by the Supreme Court with its seal of approval.

In considering the general practice of dismissing a bill on the ground of invalidity of the patent in suit, the point being raised by a demurrer, a start must be made from a well settled rule of patent practice, which is, that the question of the validity of a patent is always open to the consideration of the court, whether the point is raised in the pleading and proof or not. Where suit is brought on a patent, and the answer does not set up the defense that the patent is unpatentable, the court may sua sponte declare the patent void, even if the objection is not taken by counsel. This rule has been sanctioned by the Supreme Court in a number of cases of which Dunbar $v$. Myers and Brown $v$. Piper $^{3}$ are generally considered the leading. The rule is not unfair nor unjust to the complainants in a suit brought on letters patent, for if the patent is void, because the device or contrivance described therein is not patentable, it would ill become a court of equity to render money decrees in favor of a complainant for the infringement of a patent which the court could see was void on its face for want of invention."

If the Supreme Court on appeal can without reference to the pleadings and proof, but merely from an examination of the patent itself say that the patent is void, there appears to be no valid reason why a court of original jurisdiction cannot do the same, especially where the point is raised on demurrer." If the pleadings are not necessary to the court, why have them? Why not bring the point up immediately without the necessity of further pleadings and elaborate proof?

A patent may be declared invalid from a number of causes,

2 Dunbar v. Myers, 94 U. S. 187.

3 Brown $v$. Piper, gr U. S. 44.

4 Slawson v. Grand St. R. R. Co., 107 U. S. 679.

5. West $v$. Rae, 33 F. R. 45. 
and the cases in which the validity is tested by demurrer may roughly be divided into three classes-rst, those in which the patent is alleged to have some inherent defect apparent on its face; $2 \mathrm{~d}$, those in which the patent is alleged to be invalid in view of the state of the prior art as set forth in the bill; 3 d, those in which the prior art must be drawn from (I) common knowledge of mankind of which the court takes judicial notice, or from (2) the specification of the patent itself, and in view of which prior art the patent is alleged to lack invention.

It should be noted that in these cases, the patent itself is made part of the bill. This may be done by setting forth the patent in full, or the bill may make profert of the patent, or the patent may be attached as an exhibit. Where a formal profert is made or the patent attached as an exhibit, the courts have held that this is sufficient to make the letters patent part of the bill. ${ }^{6}$

I. Where there is something in the patent itself which is repugnant to the principles of the patent law, as for instance that the patent is for a law of nature, ${ }^{7}$ or the function of a machine ${ }^{8}$ the courts have not hesitated to declare the patent void, on demurrer, as the defect is apparent on the face of the patent.

2. A somewhat different question arises where the invalidity of a patent is established not from some defect inherent in the patent, but by extrinsic evidence. In the trial of patent cases usually the most important element in passing on the validity of a patent is what is known as the state of the prior art; which is proof of what is old and in general use at the date of the invention. ${ }^{9}$ It may consist of printed or written documents; of oral testimony of witnesses familiar with the particular art to which the invention applies; or of specimens and exhibits of devices then employed. ${ }^{10}$ This extrinsic evidence or prior art is necessary to show what was old, to distinguish what was new, and to aid the court in construing the patent.

If a patent has no inherent cause for being declared void, and extrinsic evidence is necessary to prove unpatentability, how can such evidence be presented to the court for its consideration on

6 Heaton Peninsular Button Fastener Co. v. Schlochtmeyer, 69 F. R. 594; Dickerson $v$. Greene, 53 F. R. 247; Bogart $v$. Hinds, 25 F. R. 484; Indurated Fibre Industries Co. $v$. Grace, 52 F. R. I24.

' Wall v. Leck, 6r F. R. 29r; 66 F. R. 552.

${ }^{8}$ Locomotive Works $v$. Medart, I5 Supreme Court Reporter, 75I; I58 U. S. 68 .

9 Brown $v$. Piper, gr U. S. 44 .

in Robinson on Patents, Sec. Ioso. 
demurrer, where the allegations are merely the allegations of the complaint? When the complaint contains statements or offers exhibits which set forth the prior art, this difficulty is removed. Take for example a case where two patents of different date are sued upon in the same bill. Obviously the court may consider the two patents together, and from such consideration may decide that there is no advance in the art in the second patent over the first dated, and consequently that the second is not patentable in view of the first. In Bottle Seal Company $v$. De La Vergne Bottle and Seal Company, ${ }^{11}$ the court had two patents of different dates before it, and in sconsidering the second, took the first as exhibiting the state of the prior art. An interesting case of this character is that of Russell $v$. Kern, ${ }^{12}$ where a bill in equity was brought on ten patents, and an injunction prayed for. The four earlier patents were found to have expired before suit was commenced, and the fifth in date before the return day. The court dismissed the bill in respect to these five patents for want of equity. But the first five patents, being in the bill, were considered by the court as setting forth the prior art, and on demurrer it was held no invention existed in the last five patents over the first five.

Another case of this character arises where suit is brought on a re-issued patent. In a re-issue the original patent must have been surrendered and the re-issue applied for within two years of the date of the granting of the original. ${ }^{13}$ If the original patent and the re-issue are both made parts of the bill, as exhibits, etc., and a delay of more than two years appears in applying for the re-issue, not explained by special circumstances, showing it to be reasonable, the Supreme Court has held that laches may be availed of as a defense, upon a general demurrer for want of equity. ${ }^{14}$

3. But take the third class of cases; where no earlier patent is set forth in the bill, and merely the patent sued upon and under consideration is before the court, and it contains no inherent defect. The pleadings do not present any prior art from which the court may decide the question of patentability.

The case of Brown v. Piper ${ }^{15}$ before the Supreme Court in I875, was a case decided upon bill and answer in the usual form,

1147 F. R. 6 I.

1269 F. R. 97.

${ }^{13}$ Miller v. Brass Co., 104 U. S. 350.

${ }^{14}$ Woolensak $v$. Reiher, II5 U. S. 96.

${ }^{15}$ 9I U. S. 37. 
and the patent in issue was for a process of preserving fish by freezing. In passing on the validity of the patent the court went entirely outside of the pleadings and proof, and took judicial notice of the ice cream freezer as a complete anticipation of the alleged invention. Justice Swain, in.delivering the opinion, said: "Of private and special facts, in trials in equity and at law, the court or jury, as the case may be, is bound carefully to exclude the infiuence of all previous knowledge. But there are many things of which judicial cognizance may be taken. Facts of universal notoriety need not be proved. Among the things of which judicial notice is taken, are: the law of nations; the general customs and usages of merchants; things which must happen according to the laws of nature; the meaning of words in the vernacular language, etc., etc. Courts will take notice of whatever is generally known within the limits of their jurisdiction; and, if the judge's memory is at fault, he may refresh it by resorting to any means for that purpose which he may deem safe and proper. This extends to such matters of science as are involved in cases brought before him." The court also said: "It is known that Lord Bacon applied snow to poultry to preserve it. He said the process succeeded excellently well. The experiment was made in his old age, imprudently, and brought on his last illness." Whether the court in its recital of this lamentable result of Lord Bacon's experiment would uphold the doctrine that all such facts of history may be taken judicial cognizance of, it is not safe to say. But the practice of taking notice of matters of common knowledge in patent cases, even when not set up in the pleadings, has been sanctioned by the Supreme Court also in a number of other decisions. ${ }^{16}$

The question arose in 1885 in the Circuit Court, in the case of Dick $v$. Oil Well Supply Company ${ }^{17}$ whether, where there was no answer, and the issue was raised upon demurrer to the bill, the court could also take judicial notice of matters of common knowledge in passing upon the validity of the patent. In this case and in that of Kalotype Engraving Company $v$. Hoke ${ }^{18}$ in $\mathbf{x} 887$, the courts declared that if facts existed of which the court was bound to take judicial notice, and these facts clearly established want of invention, undoubtedly the patent could be declared void on demurrer. But in neither case was the court willing to decide it on that ground, and the defendants were ordered to proceed in the usual manner by answer and proof.

16 Dunbar v. Myers, 94 U. S. 187; Slawson v. R.R., 107 U. S. 649.

${ }^{17} 25$ F. R. I05.

${ }^{18} 30$ F. R. 444 . 
In the same year as the latter of the above cases, a suit was brought in the second circuit on a patent for a design for rubber mats, having corrugations for producing varied effects of light and shade. ${ }^{19}$ The defendants demurred on the ground that there was no invention, and Judge Wallace sustained the demurrer, taking judicial cognizance of wood, plaster, and corduroy cloth, in which depressions and elevations in the surface produce variations in light and shade. Upon appeal to the Supreme Court ${ }^{20}$ the decision of the circuit court was reversed, and it was held that the demurrer should have been overruled. "Whether or not the design is new is a question of fact, which whatever our impressions may be, we do not think it proper to determine by taking judicial knowledge of the various designs which may have come under our observation. It is a question which may and should be raised by answer, and settled by proper proof."

The case of West $v$. Rae, 33 F. R. 45, decided by Judge Blodgett in the Seventh Circuit in the same year was the first wherein facts in common knowledge noticed judicially by the court, a view of mechanical patent was held void on demurrer, and hence has been looked upon as a leading case on the subject in the subsequent decisions. The patent was for paper bags for packing blankets, both ends of the bags to be pasted or otherwise secured.

The court held the patent anticipated by bags for flour, groceries, etc., in common use, of which he took judicial notice. In his opinion Judge Blodgett said: "I am not aware that the practice of raising by demurrer the question, based on common knowledge, that a patent is void for want of novelty, has the direct sanction of any adjudged case, but the books abound in cases where the court has of its common knowledge sua sponte held patents void for want of patentable novelty. In the light of these authorities I cannot see why, in a suit for infringement of a patent so clearly and baldly void as this, the court ought not to save the defendant from the vexations and expense of a trial upon proofs by sustaining the demurrer to the bill."

In the following year Judge Shipman in the case of Blessing v. Copper Works, ${ }^{21}$ which was a case at law, said: "It is well settled that in a bill in equity for the infringement of a patent, if the patent is void on its face by reason of want of patentable invention or of novelty, when the pre-existing device is a thing

${ }^{19}$ N. Y. Belting \& Packg. Co. v. N. J. Car-Spring \& Rubber Co., 30 F. R. 785 .

${ }^{20} \mathrm{I} 37$ U. S. 445 .

${ }^{21}{ }_{34}$ F. R. 753 . 
in common knowledge and use of people throughout the country, the court may stop at the instrument itself, and without looking beyond it, adjudge in favor of the defendant."

Following these two cases come a long line of decisions, some in almost every circuit, in which demurrers have been brought to the bill on the ground of the apparent invalidity of the patent, and whichever way the particular case was decided, the practice has been upheld. Judge Blodgett, in a later case ${ }^{22}$ said that at the time he announced his decision in West $v$. Rae (supra), he stated that the effect might be to encourage counsel to demur to bills for infringement of patents in cases where they, from their special knowledge of the art, might be of opinion that the device covered by the patent was old. And his anticipations in that respect were fully realized, as that decision produced in his court a bountiful crop of demurrers in this class of cases. ${ }^{23}$ The reason for this is obvious. The great cost of a long litigation is avoided if the demurrer is sustained as the validity of the patent is determined at the outset.

An exception to the general acquiescence in this practice came in the form of a vigorous protest by Judge Putnam in the First Circuit, in the case of Industries Company 2 . Grace, 52 F. R. I24, and reiterated in Henderson $v$. Tompkins, 60 F. R. 758. The latter is a copyright case but the practice under consideration received elaborate treatment therein. "No doubt," said Judge Putnam, "there is a limited class of cases in which the court must on demurrer, from the standpoint of judicial notice, disregard allegations in the bill of novelty, patentable invention, and utility. But it must be noted that there is a broad distinction between cases heard on bill, answer and proof, and those on demurrer, although it may be that in the former class the court may sometimes be compelled to dispose of questions of originality from the same common knowledge and experience which it is asked to apply in disposing of this demurrer. As Brown v. Piper (supra) was heard on bill, answer and proofs, the complainant has full opportunity, and all the facts were before the court. On such a record, the court as judges of the fact, could with propriety, say that there was nothing on the face of the patent itself which could require its attention. This distinction is not a vain one, because erroneous matter of law, if perpetuated, becomes a deformity, while findings of fact, if likewise erroneous, are swept

22 Eclipse Mfg. Co. v. Adkins, 36 F. R. 555.

${ }^{23}$ Studebaker Bros. Mfg. Co. $v$. Ill. Iron \& Bolt Co., 42 F. R. 52; Buckingham $v$. Springfield Iron Co., 5I F. R. 236. 
away and become a portion of the undigested mass of such findings. Assumption on the part of courts of knowledge which they may not in fact possess, followed by numerous dismissals of suits on demurrer woule involve the hazard of barring meritorious causes contrary to the express allegations of the bill."

A point is raised in this quotation particularly worthy of notice. The learned judge states that the court to declare a patent void on demurrer, must disregard the allegations in the bill of novelty, patentable invention, and utility. The usual, if not invariable, form of the statement in the bill as to novelty, etc., is that the patentee is the "original and first inventor of the alleged invention;" that the invention "had not been known or used by others in this country, and had not been patented or described in any printed publication in this or any foreign country before the invention and discovery thereof, and had not been in public use or on sale for more than two years prior to the application for letters patent, etc." The demurrer admits the allegations of the complaint, and yet in spite of the admitted novelty and utility of the invention, the insistent is that such novelty and usefulness are really negatived by the letters patent in question or by matters of common knowledge. Surely here is a strange incongruity. And yet in cases where the courts have particularly pointed out this glaring inconsistency resulting from the contradiction of the pleading by the contention of the defendant, the practice has been upheld and the demurrer sustained. ${ }^{24}$

The excuse for this is undoubtedly that stated in Brown $v$. Piper (supra), and to accomplish substantial justice, a seeming inconsistency in the pleadings is waived or overlooked.

In the earlier cases decided by Judge Putnam, ${ }^{25}$ it was said that the Supreme Court had in no case distinctly approved nor condemned the practice, as in N. Y. Belting and Packing Company $v$. N. J. Car Spring and Rubber Company" the decision of the circuit court was reviewed without particularly or clearly passing on the practice. Since Judge Putnam's decision two decisions have been handed down distinctly upholding the practice. The first of these was that of Risdon Iron and Locomotive Works v. Medart," and the suit was one of infringement on three patents for helt pulleys and the manufacture of the same. The defendant demurred to the bill on the ground that the patents did not

${ }^{24}$ Bottle Seal Co. v. De La Vergne Bottle \& Seal Co., 47 F. R. 59; Dick ข. Oil Well Supply Co., 25 F. R. ro5.

${ }_{25}$ Indurated Fibre Industries Co. $v$. Grace, 52 F. R. I24.

${ }^{25} 137$ U. S. 445 .

${ }^{27} 158$ U. S. 68. 
show invention upon their faces. The demurrer was argued and overruled, and the case subsequently heard upon pleadings and proof. From the decision of the lower court, appeal was taken, and the Supreme Court (Justice Brown delivering the opinion), held that the patents were invalid and the demurrer to the bill should have been sustainerl. The decision relative to two of the patents sued upon comes rather under that class of cases alluded to earlier, where an inherent defect exists in the patent -the patents being held functional, and a matter of degree, respectively. But the third patent was defeated on the prior art as set forth in the specification.

The second case by the Supreme Court ${ }^{28}$ (the opinion again being by Justice Brown) even more clearly approves the practice which is under our consideration. Here the court says: "While patent cases are usually disposed of upon bill, answer and proof, there is no objection, if the patent be manifestly invalid upon its face, to the point being raised upon demurrer, and the case being determined on the issue so formed. We have repeatedly held that a patent may be declared invalid for want of novelty, though no such defense be set up in the answer."

Moreover the patent was held anticipated by the fact that all the parts of the combination of the patent were well known, and the court took judicial notice of such common knowledge, and decided that there was mere aggregation of old parts and not a patentable combination.

Even with this sanction of the Supreme Court, the practice is still considered one to be availed of only in the clearest cases, especially in view of the many patents of seeming great simplicity which have been upheld by the Supreme Court after considering the evidence introduced in their support. "The court must be able from the statements on the face of the patent, and from common and general knowledge, to say that the want of invention is so palpable that it is impossible that evidence of any kind could show the fact to be otherwise." "so

With such strictures as to the application of the practice, many limitations may be expected in the utterances of the court as to the questions of $(r)$ what is the common knowledge to be judicially noticed by the courts, and (2) how far the specification of the patent may be considered as setting forth the prior art.

r. The court is not at liberty to apply any special or peculiar

${ }^{28}$ Richards $v$. Chase Elevator Co., ${ }_{5} 8$ U. S. 299.

${ }^{29}$ Davock $v$. Chicago \& N. W. R. Co., 67 F. R. 469, and cases cited therein.

${ }^{30}$ Am. Fibre Chamois Co. $v$. Buckskin Fibre Co., 72 F. R. 5 II. 
knowledge which it may possess, or apply to the patent the skill possessed by experts, but may only apply that knowiedge which is possessed by ordinarily well-informed people. ${ }^{31}$ Things within the common knowledge and use of the people throughout the country $^{32}$ only are before the court. In one case $^{33}$ where the patent was for a walking track, Judge Shipman said: "I am not aware of any common knowledge upon the subject of walking tracks within doors," etc. The practical difficulty and danger is in defining where special knowledge leaves off and common knowledge begins. ${ }^{34}$ Various methods of determining what is common knowledge have been suggested by counsel and considered by courts.

In the case of Brown v. Piper ${ }^{35}$ (discussed above), the court, after citing the cream treezer as an anticipation, quoted from various encyclopedias and dictionaries. Acting on this suggestion the court in American Fibre Chamois Company $v$. Williamson $^{36}$ referred to various reviews, encyclopedias and Knight's dictionary to prove that the patent was old. It might well be asked, why limit the court to dictionaries, reviews, etc.,-why not consider any sort of treatise, and all former patents, as em. braced in the common knowledge, for it most certainly cannot be urged that the ordinarily well informed person knows the contents of encyclopedias, dictionaries, etc. When the Fibre Chamois case, therefore, came before the appellate court, Judge Taft reversed the decision, ${ }^{37}$ on the ground that the court had gone out of the sphere of common knowledge into special. $\mathrm{He}$ lays down the rule that the court may refer to books of this description to support his views, if he first can point out well known instances easily within the actual knowledge of the court. In other words that the court may refresh his memory by referring to standard works. ${ }^{38}$ but not create a knowledge thereby.

The same view was taken in Bottle Seal Company v. De La Vergne Bottle and Seal Company, ${ }^{39}$ and the further point was raised whether earlier patents or designs could be considered in establishing what was common knowledge. It was held that the

a Cleveland Faucet Co. v. Vulcan Brass Co., 72 F. R. 507.

${ }^{32}$ Root $v$. Sontag, 47 F. R. 3 Io.

${ }^{33}$ Coop v. Physical Development Institute, 47 F. R. 899 .

34 Eclipse Mfg. Co. $v$. Adkins, 36 F. R. 554.

${ }^{35} 9$ I U. S. 37.

${ }^{36} 69$ F. R. 247.

${ }^{37}$ Am. Fibre Chamois Co. $v$. Buckskin Fibre Co., 72 F. R. 514.

${ }^{38}$ Brown $v$. Piper, 91 U. S. 37.

${ }^{39} 47$ F. R. 63 . 
only way by which knowledge of anticipating devices or letters patent could be brought to the court was by due and legal proof.

"It has never been supposed that letters patent could be taken judicial notice of by the courts. There is nothing in their character nor their contents to so dignify them. They are simply contracts reduced to writing, capable of being recorded, and of being proved in a particular way." So Judge Coxe held ${ }^{40}$ regarding a number of exhibits introduced with the demurrer.

2. As to the extent in which the specification of the patent may be considered as setting forth the prior art, there appears to be an irreconcilable disagreement in the adjudged cases. On the one hand there are numbers of cases in which the statements of the patentee as to the previous methods or devices over which he has improved, are taken as admissions on his part as to the prior art, and from such statements the patentability of the particular patent decided. On the other hand courts have refused to be bound by the statements as they appeared in the specification, without an opportunity being given the complainant to explain or construe such seeming admissions." Judge Putnam gives utterance to the following", "A bill in equity does not necessarily make all the statements of fact contained in a contract or letters patent proper parts of the pleading by making profert, or reciting the tenor at length. In letters patent the claims become a fundamental part of the bill and so much of the specification as is necessary to construe the claims. But all portions which merely set forth the state of the art are like recitals of facts in contracts or other instruments, more or less conclusive on the party who sets them up, yet in law explainable and not absolutely presumed to have been so alleged as to become the subject of demurrer. * * * It is true that so far as the specification contains any representations which, if erroneous, may be presumed to have misled the Patent Office to the detriment of the public, the patentee may be estopped. On the other hand, I do not understand that the law has gone so far as to forfeit a valuable patent because the patentee has inaptly or somewhat inaccurately, described the state of the art, or that it conclusively prohibits him from showing such inaptitude or inaccuracy, if it also appears that the public has not been prejudiced thereby." In commenting on this language Judge Sage presents the opposite view in Heaton Peninsular Button Co. $v$. Schlochtmeyer, ${ }^{43}$

${ }^{40}$ Lalance \& Grojean Mfg. Co. v. Mosheim, 48 F. R. 452.

11 Coop v. Savage Physical Development Co., 47 F. R. 899.

${ }^{2}$ Indurated Fibre Industries Co. v. Grace. 52 F. R. 124. 
(since affirmed by the circuit court of appeals in the Sixth Circuit"1s), thus: "The patent is the title deed through which the complainant must derive all his rights. It is the grant of a monopoly, and with rare exceptions, every statement of the prior state of the art therein contained bears upon the construction, and is a limitation of the grant. The description in the specification of the existing art, and of the applicant's improvements, form the representations upon which he obtains the grant. Having done so, he is estopped to say that his representations were incorrect. If the recitals of the state of the art do not tend to limit, explain, or nullify the grant, they are of no possible pertinence, even if the same facts were fully proved aliunde. If, on the other hand, they do have such tendency, the patentee is bound thereby, and the patent must be construed in the light of the facts so recited."

In two cases ${ }^{45}$, the courts have declined to consider prior patents cited in the patent in suit, showing the prior art, as before them for their consideration. The mere fact that reference is made to a former patent, does not bring that patent to the knowledge of the court or spread its claims or description upon the record. It must be proved by legal testimony in the usual way.

Where the patent in issue contains a specific disclaimer, the courts have considered such disclaimers as admissions on the part of the patentee, and from them determined the prior art.

A minute study of the statements of the prior art in the patents in the various suits ${ }^{36}$ is apt to lead to the conclusion that almost any statement in the patent may be considered by the court as setting forth the prior art and as an admission and part of the bill. Especially does this statement seem correct in view of the Supreme Court case, Locomotive Works $v$. Medart", where the court took the usual statement of the specification as to previous devices as an admission on the part of the patentee as to the prior art.

If this conclusion is correct it behooves solicitors of patents to be more careful of their statements of the prior art, or else confine themselves strictly to a description of the device in hand and avoid all mention of the prior art, as they would ice marked "Dangerous."

${ }^{43} 69$ F. R. 592.

1472 F. R. 524 .

${ }_{15}$ Drainage Construction Co. $v$. Englewood Sewer Co., 07 F. R. I4I; Cleveland Faucet Co. v. Vulcan Brass Co., 72 F. R. 506.

${ }^{16} 6$ I F. R. 29 r ; 47 F. R. 309; 72 F. R. 508, and others.

${ }^{47}{ }_{5} 8$ U. S. 68. 